\title{
The Age of Crime - A Cognitive-Linguistic Critical Discourse Study of Media Representations and Semantic Framings of Youth Offenders in the Uruguayan Media.
}

\author{
Maria Julios-Costa \\ Lancaster University
}

\begin{abstract}
The present study integrates corpus-assisted text analysis with frame semantics to study a social problem. Taking a cognitive-linguistic approach to CDS (Hart, 2011a, 2014), in this article I examine the linguistic construction of minors (viz.: people aged 13 to 18) in a corpus of 489 articles from Uruguayan newspaper "El País" in the context of the so-called "Criminal Imputability Referendum". Throughout, I find evidence to the effect that minors and adolescents are recurrently placed within the frame of CRIME, and, within this, the frame elements they profile (as per the mappings in FrameNet -see FrameNet, 2014, n.p.) are those of Perpetrators of violent crimes rather than Victims (e.g. of abuse and domestic violence). I argue that, in the context of the referendum, these discursive strategies run the risk of facilitating the consolidation of a strong conceptual link whereby youth becomes readily associated with criminality (ignoring other aspects of children's situation in Uruguay such as their waning access to education, child poverty, child protection laws, or health issues), and are subservient to the political views of groups supporting a lower cutoff age for criminal responsibility and more stringent punishments. The observations arrived at in this instance set the foundations for a later experimental study testing whether the discursive patterns unearthed here have an effect on how readers conceptualise minors outside the texts.
\end{abstract}

Word Count: 9,744

Byte size: $517 \mathrm{~KB}$

Corresponding Author:

Makarena Julios-Costa. 51 Half-Moon Lane, Spennymoor, DL16 6HQ Email: m.julioscosta@gmail.com

Maria Julios-Costa is a graduate of the MA in Linguistics at Lancaster University. Her research interests are focused on exploring the cognitive and emotional bases of ideology, discrimination and social policies through text analysis and experimental methods, primarily taking a cognitive linguistic approach to CDA. 


\section{Introduction}

This study examines the representations of minors in the Uruguayan media in the context of the "Criminal Imputability Referendum". The aim of this study is to describe the linguistic patterns whereby minors (citizens under 18 years of age) are constructed in media texts and how these representations relate to specific discourses which may serve to fixate a conceptual association of adolescence with criminality in readers' minds, and to reinforce the political arguments in favour of reducing the age of criminal responsibility, a key point around which said referendum (see below) revolved.

As a theoretical and analytical backdrop, I take a cognitive-oriented approach to Critical Discourse Studies (Hart, 2014; Van Dijk, 2008). In the following sections of this article, I delineate the sociopolitical backdrop of the "Criminal Imputability Referendum", and explore some useful theoretical considerations regarding the role of cognition in social action and the formation of social attitudes. This is followed by an analysis of previous research of cognitively-oriented CDA studies exploring a host of mental operations ostensibly associated with the prevalence of discrimination and power imbalances. The text analysis that ensues consists of a broad-brush exploration of discursive macrostructures and dominant frames (observed via word frequencies and collocations) in a corpus of 489 articles (approximately 220,000 words) with youngsters as a thematic centre, followed by a fine-grained concordance analysis which focuses on semantic frame configurations in a subset of 5 texts that are to be used as input in an experimental examination of the effects of media discourse regarding young offenders on readers' conceptualisations of events outside the texts (Julios-Costa, forthcoming). I also propose future lines of research to expand on this study.

\section{Context of Analysis: The Criminal Imputability Debate - Uruguay at Odds with Human Rights}

The so-called "plebiscite on the criminal imputability of minors" was a popular vote which took place in the 2014 general elections in Uruguay following years of campaigning from center-right sectors of the opposition for more repressive measures against youth crime. As a central demand, these groups sought to lower the cutoff age of criminal responsibility from 18 to 16 years of age. This meant that citizens from 16 years of age were to be transferred to the adult penal system, despite warnings by the UN and independent bodies that it would violate adolescents' right to a specialised penal system ${ }^{1}$-as spelled out in the Interamerican Charter of Human Rights, of which Uruguay is a signatory (UNICEF, 2014). Besides calls to lower the minimum age of imputability, reformers demanded to keep all offenses on the criminal record of citizens after they turned 18; to make imprisonment mandatory from 16 years of age onwards (with no opportunity for alternative punishments); and to increase by an average of four times the minimum time of imprisonment for certain offenses.

To justify placing people as young as 16 within an adult penal system already marred by overpopulation and a markedly precarious observance of human rights (see report by Bureau of Human Rights, 2013 and United Nations, 2009), reformers constantly referred to purported spikes in crimes committed by young adolescents, and echoed the widespread belief that youngsters committed more violent crimes than adults (see UNICEF, 2010). Yet, while most of the public did espouse these views (69\% in 2009 -see Equipos Mori, 2009), in reality, there was little statistical evidence to support them, and very little conclusive data

${ }^{1}$ From 2004, minors in Uruguay were prosecutable under a specialized system contained in the Code of Childhood (fashioned after UNICEF's Code of Childhood). 
backing what reformers alleged were uncontrollably steep increases in youth crime (as has been proven by UNICEF, 2012, 2014).

In the years leading to the plebiscite, youngsters in Uruguay had long been in an extremely delicate socioeconomic situation. The 2002 economic crash uncovered and exacerbated a host of problems that would beleaguer Uruguayan children and adolescents for decades. Among these were high levels of infantile poverty (see CEPAL, 2010), unequal access to wealth across families from different social sectors (Paternain, 2008), school disengagement (UNICEF, 2012) and widespread exposure to domestic violence (InFamilia, 2009). Furthermore, violent crime in general and with it, youth crime, were on the increase (Paternain, 2012). Eventually, discontent with the structures of social control became commonplace (Paternain, 2012), and widespread expressions of dissatisfaction were recurrent topics of public discussion. By dint of political action, popular belief and media coverage, minors and young offenders, especially those of uneducated and underprivileged backgrounds, came to be placed at the center of public controversy -one which glaringly ignored the complexity and vulnerability of their position in Uruguayan society.

In the end, the reforms were not passed, yet, worryingly so, a large sector of the population $(41 \%)$ did vote in favour of the potential human rights violations the plebiscite advocated. As a result of the pressure by political groups, media coverage and the public, a number of the more repressive measures the plebiscite called for were put in place by the government before the elections (e.g.: keeping criminal records, making imprisonment mandatory). It is from media discourses in this socio-political context that my data is extracted.

\section{CDA, Cognitive Linguistics and Social Problems - Cognition at the Root of Social Action}

Cognitive-Linguistic Critical Discourse Studies (henceforth CL-CDS) posits that the role of discourse in society is mediated by cognition (Wodak, 2006). How social actors understand their context, how they construe themselves and other social groups in text and talk, is informed by both individual cognitive mechanisms and social cognitions i.e.: socially shared systems of knowledge, beliefs and values, of which ideologies are part (following van Dijk, 2008). The focal point of this approach is on the exploration of the cognitive patterns which shape and are shaped by the discursive practices of different social groups. Ultimately, as with all CDA, CL-CDS aspires to unveil how these practices serve to present ideological presumptions as objective and righteous, and (potentially or in effect) perpetuate power imbalances and discriminatory practices (Wodak and Meyer, 2009; Fairclough, 1989).

One major source of theoretical and descriptive import in recent CL-CDS research originates in Cognitive Linguistics. This is partly because, in line with CL-CDS, Cognitive Linguistics offers a conceptual approach to the study of language (Croft and Cruse, 2004 -see Hart, 2014 for a discussion on the synergy between CL and CDA).

CL aims to offer cognitively plausible accounts (Hart, 2014) of the way in which language, the mind, and experience interact to produce meaning. At the core of this relationship are construal operations. These are mental processes (aided by non-linguistic faculties such as visual and spatiotemporal perception, reasoning, memory and attention) which speakers perform in order to produce and understand language in different social and physical contexts. As members of a social collective, construal allows us to conceptualise and build up a certain picture of reality with the cues we get from socially shared knowledge and individual mental and emotional structures. Ideologies, being systems of beliefs and attitudes, are part and 
parcel of such construals within social life. Indeed, CL theorises that "ideology is a conceptual system of a particular kind" (Lakoff, 1996: 37).

Hart (2011a, 2014) presents an account of how construal operations could function at the service of ideology in discursive action. In his taxonomy, construal processes instantiate discourse strategies, understood as "more or less intentional/institutionalised plans of practices whose realisation achieves particular cognitive, emotional and/or social effects" (Reisigl and Wodak, 2001; Hart, 2015: 327). These strategies serve to disseminate ideology and forward certain worldviews, with a view of influencing social action.

In the present article, the investigative focus lies on the construal operation of categorization, and the discursive strategy of framing. Categorization involves the application of a linguistic construction to a social actor or entity; e.g.: labelling a minor as "murderous". In social action, categorization is realised discursively and contextualised through framing (Fillmore, 1982), i.e. the process whereby, through language use, a social actor or event is placed within a socially shared network of meanings, beliefs and/or patters of practice used to make sense of experience, i.e.: a frame (Fillmore and Baker, 2009: 314-cf. social schema theory by Fiske and Taylor, 1991). Since such knowledge is given by our involvement in the physical world and our culture (Croft and Cruse, 2004), it can reflect attitudes and assumptions about aspects which integrate those worlds. Part of that meaning is culturally constructed and choiceoriented, and as such, it is open to negotiation and ideological struggle.

\section{Studies on Language and Cognition - CDA and the Cognitive Turn}

Investigations that draw from CL to study the development and legitimization of ideologies are only starting to be considered valid and revealing ways of doing CDA. That "cognitive turn" in CDA responds to critiques about many CDA scholars being largely unconcerned with going beyond the identification and description of ideological constructions (Flowerdew, 1999) and into the realm of grounded interpretations, i.e. of the effect that those constructions actually have on the speakers' knowledge systems used in representing the world (see Van Dijk, 2008; Chilton, 2005/2011; Hart, 2010). While descriptive CDA provides a valuable first step into the demystification of ideologies and discourse orders, approaches such as that of CCDA offer plausible explanations (grounded in psychological and cognitive sciences) as to why and how those orders form and are upheld in the first place.

Some of the most notable examples of research about the role of cognition in the making and upholding of ideology come from studies which look into the cognitive structures at work in perpetuating anti-immigration and racist discourse. Conceptual metaphors have taken the lion's share of the attention in such CCDA studies (see El Refaie, 2001; Charteris-Black, 2006; Koller, 2004; Musolff, 2010), with mental spaces (Hart, 2008) and deixis and perspectivization (Chilton, 2004; Kaal, 2012) also being taken up as plausible construal systems set in motion in the formation and maintenance of ideologies which disparage immigrants. Such studies have normally focused on how these systems are realized by lexical items, expressions of modality and broad macrostructures of discourse. Construal operations beyond metaphor and deixis have figured much less prominently in CCDA studies, but are beginning to gain momentum. For instance, Sánchez-García (2007), and Sánchez-García and Blanco-Carrión (2007) apply FrameNet (a database of semantic frames with the core and non-core elements making up each frame, including their potential semantic and syntactic combinations -Sánchez-García and Blanco-Carrión (2007)) in elucidating the framing strategies and image schemata activated when 
describing emotional responses to violence. Even if they do not define construal operations explicitly, their analysis considers the linguistic mechanisms involved in particular framings of an event as well as the attentional processes involved. In closer relation to the construal operations observed in the present dissertation, Hart (2011a, 2011b) offers an exploration of the lexicogrammatical structures employed in the setting up of ideological stance regarding the Student Riots as they are derived from the operations of force dynamics and focal attention. More recently, Hart (2014) has delved into the cognitive strategy of positioning, arguing that the construction of meaning through discourse involves visuo-spatial properties (ibid., p.103) and social actors' use of grammatical constructions is done in terms of the point of view they wish to invoke in representing their interests.

The present study exploits the potential of framing as a strategy whose analysis in text can both help demistify the ideological substrates behind text producers' content decisions and linguistic expressions employed in producing said content, and explain the potential effects of such discursive representations on readers' minds. Here, I derive the input for my analysis from Uruguayan newspaper El Pais, as it is by far the most widespread print media outlet in the country (Radakovich et al., 2013). Below, I proceed by carrying out a macrostructural discursive analysis of a corpus of naturally occurring texts, and identify the most prevalent frames therein used to construe people under 18, by observing word frequency and collocations. Following that, I randomly select a sub-sample of texts from the broader corpus and carry out a fine-grained analysis of how these frames are configured at a micro level and the perceptions about minors which they facilitate. The results of the analysis carried out here provide the foundations for a later study reporting on the effects of the discourse configurations revealed via the text analysis; specifically on how a group of participants made sense of the perpetrators of a crime event in an image after being exposed to the sub-sample of texts (Julios-Costa, forthcoming).

\section{Representing Youngsters in El Pais.}

\section{Text Analysis of Discursive Macrotopics}

The corpus of articles making up the dataset of the present study was constructed using the database LexisNexis. The first step entailed searching for articles containing the keywords "menor*" (minor*), "adolescent*" or niñ (child*), either in the headline or the body of the article in more than four instances. This permitted the selection of texts where the main (or one of the main) thematic foci revolved around people under 18. Furthermore, only texts published between 2011 and 2014 (i.e. close in time to the Imputability Plebiscite) were extracted. This process yielded a body of 489 articles.

Using AntConc software, the most frequent words in the corpus were identified. In the whole word frequency list of 489 articles, items profiling the general frame of CRIME, such as "felony", "prison" or "armed robbery", were dominant. Words related to areas such as education, youth health or recreation were much less frequent. So much so that, within the 30 most frequent content words, 15 were instances of the CRIME frame - this can be seen in table 1. 
Table 1 - Top 30 Words by Frequency in General Corpus (489 articles)

\begin{tabular}{|c|c|c|c|}
\hline Rank & Raw Frequency & Word Type & Translation \\
\hline 1 & 1966 & menor* & minor* \\
\hline 2 & 1258 & niño* & child* \\
\hline 3 & 1227 & años & years \\
\hline 4 & 1054 & adolescente* & adolescent* \\
\hline 5 & 674 & caso* $^{*}$ & case* $^{*}$ \\
\hline 6 & 612 & INAU & $\begin{array}{l}\text { INAU (Uruguayan } \\
\text { Institute of the Child } \\
\text { and Adolescent) }\end{array}$ \\
\hline 7 & 586 & país & country \\
\hline 8 & 516 & policía* & police \\
\hline 9 & 507 & joven* & youngster* \\
\hline 10 & 497 & juez* & judge* \\
\hline 11 & 427 & año & year \\
\hline 12 & 417 & delitos & felony* \\
\hline 13 & 397 & hogar* & home* \\
\hline 14 & 379 & centro* & center* (prison) \\
\hline 15 & 361 & edad* & age* \\
\hline 16 & 335 & rapiñ* & armed robbery* \\
\hline 17 & 319 & familia* & family* \\
\hline 18 & 319 & madre* & mother* \\
\hline 19 & 318 & mes* & month* \\
\hline 20 & 273 & homicidio* & homicide* \\
\hline 21 & 272 & judicial & judicial \\
\hline 22 & 270 & antecedentes & criminal record* \\
\hline 23 & 264 & montevideo & Montevideo \\
\hline 24 & 260 & justicia & justice \\
\hline 25 & 260 & lugar* & place* \\
\hline 26 & 252 & medida* & $\begin{array}{l}\text { measure* (of } \\
\text { internment) }\end{array}$ \\
\hline 27 & 242 & padres & parent* \\
\hline 28 & 234 & día* & day* \\
\hline 29 & 230 & sistema & system \\
\hline 30 & 227 & juzgado & courthouse* \\
\hline
\end{tabular}

The dark red color corresponds to words within the CRIME frame, while the light blue marking is for words within the frame LAW \& INSTITUTIONS which in the texts are almost exclusively related to crime events (i.e. these are institutions that appear as actors in CRIME event frames). Words in dark blue profile the semantic frame FAMILY \& PARENTING. These general frames are adapted from a previous content analysis by Vilela-Sánchez (2006), which provides an exploratory account of the most frequent media macrotopics in media reports about children, minors and adolescents.

Following the examination of word frequency, a collocation analysis (taking t-scores of 2 or more as significant, following Hunston, 2002) was carried out for the three keywords upon 
which the main search was performed. For "minor*" and "adolescent*", the strongest collocates were words within the CRIME frame. This suggests quite strongly that an overwhelming majority of articles about young adolescents in this newspaper are thematically focused on the dimension of crime and that there is a systematic association of minors with criminality. For reasons of space and focus, a more detailed description of this stage of the analysis is included in the appendix.

\section{Text Analysis at Micro-Level - Quantitative and Qualitative Patterns}

From the wider corpus of 489 articles, five texts were randomly selected ${ }^{2}$ to be part of the input to be used in an experiment assessing the impact of exposures to discourses that conceptually pair minors and adolescents with violent crime on how readers judge the ages of two perpetrators in a picture of an armed robbery (Julios-Costa, forthcoming). In this random selection, unsurprisingly, the thematic focus of all five articles revolved around youngsters and their involvement in crime. In the end, the selection process yielded two types of articles: one consisted of reports of a specific instance of a robbery or murder (three of the five articles), and the other comprised articles discussing social and statistical aspects of youth crime in Uruguay (the remaining two articles).

For the text analysis of this sample, linguistic constructions of minors were identified and extracted via AntConc and then manually tagged according to the semantic frames they activated and the roles that minors fulfilled within these frames. The FrameNet frame index was consulted as a reference for the tagging process. FrameNet (Baker, Fillmore and Lowe, 1998) is a database which contains a directory of different event frames with their corresponding constitutive elements ${ }^{3}$. Event frames (EFs) are here considered to be more specific instances of general frames, in that they give "a description of a type of event, relation, or entities and participants" (FrameNet, 2014, n.p.) that can be located within general frames. For example, in the frame CRIME, EFs such as "Robbery" are contained. This EF carries more specific and contextually-dependent meanings than "CRIME", as it refers to a specific type of crime. In turn, within each event frame there is a number of frame elements (F.ELs) that act as the constitutive pieces of an event. In "Robbery", for instance, FrameNet lists elements such as Prisoner and Prison Institution as core F.ELs (i.e. elements that must be there for that frame to be recognized through language), and a number of non-core F.ELs, such as the Crime_committed, Time (i.e. duration of incarceration), Authorities (ruling the incarceration), etc. The same happens for the frame AGE, another central frame in the sample, with the EF "People_by_Age" being ubiquitous due to the thematic focus of the articles, and with F.ELs such as "adolescent", "child" or "minor" being dominant in the sample.

Taking FrameNet's index of event frames as a guide, the EFs and corresponding elements within the CRIME domain that appeared in the sample texts (in relation to minors) are in the table that follows. The F.ELs in the chart are listed exactly as they appear in FrameNet's index, yet it is to be noted that not all of the listed F.ELs appear in the sample; the meaning and functions of each will be expanded upon if and when they are activated in the texts.

\footnotetext{
${ }^{2}$ Using the Excel random ordering function.

${ }^{3}$ While FrameNet is based on English language, the EFs related to the CRIME frame (shown in Table 1) which appear in the texts, as well as their constituing elements are virtually identical for Spanish. A Spanish version of FrameNet is still under construction.
} 
TABLE 1. Event Frames and Frame Elements in Sample Texts

\begin{tabular}{|c|c|c|}
\hline Event Frame & Core Frame Elements & Non-core Frame Elements \\
\hline Arrest & $\begin{array}{l}\text { Authorities; Charges; } \\
\text { Offense; Suspect }\end{array}$ & $\begin{array}{c}\text { Co-participant; Manner; } \\
\text { Means; Place; Purpose; } \\
\text { Source of legal authority; } \\
\text { Time; Type } \\
\end{array}$ \\
\hline Being_incarcerated & Prison; Prisoner & $\begin{array}{c}\text { Authorities; Crime; } \\
\text { Duration; Manner; Place; } \\
\text { Reason; Time } \\
\end{array}$ \\
\hline Cause_harm & $\begin{array}{l}\text { Agent; Body part; Cause; } \\
\text { Victim }\end{array}$ & $\begin{array}{c}\text { Circumstances; Degree; } \\
\text { Duration; Explanation; } \\
\text { Frequency; Instrument; } \\
\text { Manner; Means; Place; } \\
\text { Purpose; Reason; Result; } \\
\text { Time } \\
\end{array}$ \\
\hline Committing_crime & Perpetrator; Crime & $\begin{array}{l}\text { Frequency; Instrument; } \\
\text { Manner; Means; Place; } \\
\text { Purpose; Reason; Time }\end{array}$ \\
\hline Criminal_process & $\begin{array}{c}\text { Charges; Court; Defendant; } \\
\text { Defense; Judge; Jury; } \\
\text { Offense; Prosecution }\end{array}$ & Place; Time \\
\hline Escaping & $\begin{array}{c}\text { Escapee; Undesirable } \\
\text { location }\end{array}$ & $\begin{array}{c}\text { Degree; Depictive; } \\
\text { Distance; Explanation; } \\
\text { Goal; Manner; Means; Path; } \\
\text { Place; Purpose; Speed; } \\
\text { Time; Vehicle }\end{array}$ \\
\hline Killing & $\begin{array}{l}\text { Cause; Instrument; Killer; } \\
\text { Means; Victim }\end{array}$ & $\begin{array}{c}\text { Degree; Manner; Place; } \\
\text { Purpose; Reason; Result; } \\
\text { Time } \\
\end{array}$ \\
\hline Prison & Penal institution & $\begin{array}{c}\text { Inmates; Location; Name; } \\
\text { operator; Security }\end{array}$ \\
\hline Robbery & Perpetrator; Source; Victim & $\begin{array}{c}\text { Co-participant; Frequency; } \\
\text { Goods; Manner; Means; } \\
\text { Place; Purpose; Reason; } \\
\text { Time }\end{array}$ \\
\hline Shotting_scenario & Agent; Projectile & $\begin{array}{l}\text { Area; Degree; Distance; } \\
\text { Firearm; Goal; Manner; } \\
\text { Means; Path; Purpose; } \\
\text { Source; Time }\end{array}$ \\
\hline
\end{tabular}

Of the 882 words in the sample, there is a notably high density of linguistic constructions activating the semantic frame CRIME, with almost 20\% (172 lexical items) being activations of crime-related conceptual structures (e.g. "homicidal" "firearm", "violent", "delinquents"). Furthermore, in every instance of the words "minor*" and "adolescent"" (45 occurrences) there is subsequent activation of EFs related to CRIME (e.g. in the headline " 80 homicidal minors in detention centres"). This means that, in this sample, minors are being exclusively construed as frame elements in events of violence and illicit acts.

However, the sole presence of AGE-related and CRIME-related lexical items in the frequency and collocations lists does not tell us anything, qualitatively speaking, about their actual 
semantic combinations and the role that minors are construed as having played in those event frames. For example, references to minors could be occurring within crime events in which minors figure as victims or witnesses. It is by taking a closer look at each case that we find that minors are exclusively constructed as the Perpetrators in these EFs.

In extracting and tagging every concordance of "minor*", "adolescent*" and "children*" according to their frame configurations, and examining its semantic import qualitatively, we find that minors appear within two predominant frames: the nonspecific "Committing Crime" (35\% frame events related minors to crime perpetration) and "Robbery" (31\% construed them as robbers); and in them, minors always profile the F.EL Perpetrator.

The very frequent appearance of the first EF ("Committing_Crime") is quite revealing in that the lexical items that activate it are usually quite hyperonymic and generic. The very nature of the EF "Committing_crime" is that of a nonspecific crime event (compare that to "Robbery" or "Killing", which are specific kinds of crimes). In the activation of this EF, minors often appear next to the words "delincuentes" (delinquents) or "bandas" (gangs), or are construed as committers of unspecified "felonies". Take the following examples (bolds are mine):

\section{Original}

1) Menores cometen tres delitos por día. Estadísticas del Poder Judicial señalan que la participación de los menores en delitos en general ha ido en aumento en los últimos años.

2) Los precoces delincuentes ingresaron a la policlínica Colón del Círculo Católico, próximo a las tres de la tarde. Los menores fueron directamente a la caja.

3) Banda de menores azota el barrio Colón.

4) Tras una persecución, dos delincuentes fueron capturados.

\section{Translation}

Minors commit three felonies a day. Statistics from the Judicial Power point out that the involvement of minors in crime in general has been on the rise in the past years.

The precocious delinquents entered the Círculo Católico clinic at Colón, around three in the afternoon. The minors went straight to the cash register).

Gang of minors scourge neighborhood of Colón.

After a chase, two delinquents were captured.

In all of these cases, the links to criminality that these minors have are construed as static and long-lasting, as an existential characteristic that these (largely undifferentiated) groups of youngsters exhibit. Examples of this are nouns such as "delinquent", "gang" or "felonies". In these framings, minors are being simply represented by virtue of their role as crime committers, and contextual factors, such as, e.g., the reasons these crimes happen (listed on FrameNet as frame element Explanation), and more specific sociocultural characteristics of this bulk of minors construed as obscure perpetrators, are backgrounded or simply not mentioned -even when articles reflect on the overall situation of youngsters in relation to crime in Uruguay. As hinted at above, the frames that are activated by these construals of minors are for nonspecific "crimes", and the absence of any frame elements that specify the types of crimes these are is arguably more conducive to entrenchment (Hart, 2008, p. 110; see Divjak, 2015) of a stereotyped association of young age with crime in the mind (we examine whether there is evidence for this in the experimental test in Julios-Costa, 
forthcoming). Still, the background of the victims is often discussed (see text 3 in the appendix).

In example 1, saying that "minors commit three felonies a day" puts forward the view that this is a permanent habit that they all have, i.e. that their everyday activities consist of committing (three) crimes each day. In this manner, such a characterization brings to mind the notion of a repetitive, routine action. Moreover, the lack of any modifier for "minors" that could potentially narrow down or specify who these minors are gives the idea that it is all minors who commit three crimes a day, and undercuts the possibility to reflect upon why this trend may apply to some youngsters in Uruguay. The fact that details that could better contextualize the information are omitted from the headline, which is the most prominent element in a hard news article (White, 2005), means that the focal attention is on a generic, negatively charged characterization which exacerbates the dimension of danger that minors seem to embody as a product of their very nature; they are "felons" in general. This is most clear when minors are construed in terms of their participation in "crime in general", quoting unspecified statistics by the Judicial Power and presenting the idea that minors have been increasingly involved in all kinds of crimes in the years the imputability debate went on with no further details (see example 7). In example 4, an attitudinal modifier ("precocious") is appended to the noun "delinquents". This means that the construal which is privileged for these offenders is within the remit of general criminals, i.e. "delinquents", who also are felons at an earlier age than expected (a claim which most supporters of the plebiscite openly espoused). By placing such general categorizations in the context of describing an actual robbery, it becomes ostensibly easier and more normalised to append a hyperonymic term such as "delinquent" to minors -a word which, in Spanish, is used mostly to describe adult offenders.

For the second most common EF in the sample (i.e.: "Robbery"), minors and adolescents are also without exception activators of the F.EL "Perpetrator". Some examples are:

\section{Original}

6) Armados hasta los dientes, cuatro delincuentes menores robaron un restaurant en Pocitos.

7) Los adolescentes cometen más rapiñas que los adultos, sin importar que el número de menores delinquiendo sea más pequeño.

8) Mientras comerciantes y vecinos preparaban una marcha para reclamar seguridad, la policlínica era asaltada por tres menores de 8,10 y 14 años

9) Los menores actúan con cada vez más violencia en sus rapiñas a comerciantes o transeúntes.

\section{Translation}

Armed up to their teeth, four minor delinquents robbed a restaurant in Pocitos

Adolescents commit more armed robberies than adults, no matter that the number of minors committing crimes is smaller"

While traders and neighbours prepared for a march to demand safety, the health clinic was robbed by three minors aged 8,10 and 14 years

Minors act with more and more violence each time in their armed robberies of merchants or pedestrians.

In example 6, two core F.ELs are employed in the construal of the robbery. The noun phrase "four minor delinquents" activates the FE "Perpetrator" and "a restaurant in Pocitos" constitutes the Source, i.e. "the initial location of the [stolen] goods, before they change location" (FrameNet, 2014, n.p). Besides these central F.ELs, non-core F.ELs related to crime are also activated to complete the representation of events. These are utilized to describe the 
manner in which these crimes were carried out -especially to indicate the violent, seemingly uncompromising nature of the perpetrators - and to offer other circumstantial details. These

\section{TABLE 2. Configurations of Main Event Frames and Supporting Frames in Example 1}

\begin{tabular}{|c|c|c|c|c|}
\hline \multirow{2}{*}{\begin{tabular}{|l} 
Propositional \\
Content of \\
Clause \\
Complex \\
\end{tabular}} & $\begin{array}{l}\text { Armados hasta } \\
\text { los dientes }\end{array}$ & cuatro delincuentes menores & robaron & $\begin{array}{l}\text { un restaurant } \\
\text { en Pocitos }\end{array}$ \\
\hline & $\begin{array}{l}\text { Armed up to } \\
\text { their teeth }\end{array}$ & four minor delinquents & robbed & $\begin{array}{l}\text { a restaurant } \\
\text { in Pocitos }\end{array}$ \\
\hline \multirow{7}{*}{$\begin{array}{l}\text { Configuration } \\
\text { of Main EFs } \\
\text { and } \\
\text { Supporting } \\
\text { EFs }\end{array}$} & "artion: & Core FE: & \multirow{6}{*}{ Action } & \multirow{6}{*}{$\frac{\text { Core FE: }}{\text { Source }}$} \\
\hline & Non-core & Sunnorting FF. & & \\
\hline & & $\begin{array}{l}\text { Supporting EF: } \\
\text { Committing_Crime }\end{array}$ & & \\
\hline & $\begin{array}{l}\text { (up to } \\
\text { their teeth) }\end{array}$ & Core FE: Agents & & \\
\hline & \multicolumn{2}{|c|}{ Supporting EF: Shooting_Scenario } & & \\
\hline & $\frac{\text { Non-core }}{\text { FE: Manner }}$ & Core FE: Perpetrators & & \\
\hline & & Main EF: Robbery & & \\
\hline
\end{tabular}

are "Manner", realized by the participial clause "Armed to the teeth". Additionally, there are two supporting CRIME EFs at work here, within the one clause complex, adding to the construal of minors as robbers with a clearly negative attitudinal disposition. The visual rendition of these event frame interactions is shown in table 2 , followed by the corresponding explanation.

Apart from the main EF, which is Robbery, one of the supporting frames is "Committing Crime". This is because the noun group "four minors", besides activating the Perpetrators of the Robbery, has the modifier "delinquents" in it, and this means that the noun phrase it forms will also activate the more general EF "Committing_crime". Again, we see an example of the hyperonymical adjective "delinquent", more normally used for adults, being used to categorize minors. As mentioned before, using such a construal traditionally reserved for adult offenders constitutes one possible strategy whereby minors begin to be brought conceptually closer to adults when they are involved in a crime (arguably making it conceptually easier to transfer them to a frame of adult criminal law).

The other supporting EF corresponds to Shooting_Scenario, since it is reported in the example that the perpetrators of the robbery were "armed up to their teeth". The participle "armed" triggers in the mind a scenario of weapon wielding (most probably firearms, seeing the modus operandi of these crime events across the corpus), and so of a shooting scenario (even if the weapons were not actually discharged). The addition of this EF helps to construe the view that not only are minors robbing, but they are doing so with an excessively violent and dangerous disposition. Hence we also get the intensifier "up to their teeth", which in Spanish is highly colloquial and conforms to a notably negative attitudinal construction of the way these minors go about the robbery. Such a construal could play very noticeably in the emotional schemata of readers who, besides possibly having a negative emotional response triggered by the narration of four youngsters committing a robbery, will be impacted even more by the strategic addition of this linguistic construction. 
In a sense, the EFs identified in this example can be said to constitute a set of Chinese boxes. By choosing to use such linguistic constructions, it could be argued (as is indeed the case in CL-CDS) that the writer has a certain amount of control over (his/her choices of) the portions of the reality being selected and profiled and over the kinds of cognitive structures and semantic frames that the reader (as a member of the same culture) will need to activate in order to make sense of the utterance. Adding these additional EFs to the example above seems to work to amplify the sense of threat created by the youngsters being reported here since, at the same time, they are involved in a Robbery, a Shooting_Scenario and exhibit what is constructed as their inherent link to Committing_Crimes. Additional cases of this can be found in the texts, e.g.: "Minors stone [drivers] (EF Attack), rob them (EF Robbery) and return home (EF Escaping) to their "responsible" guardians", or "Eighty homicidal minors (EF Killing) are interned (EF Imprisonment) in Colonia Berro"

Example 7 puts adolescents and adults into direct contrast by construing adolescents as more likely to be perpetrators of an armed robbery than adults. This example is located within an article which purports to offer a statistical report of the commission of crimes by minors, and resorts to a comparison of criminal levels between the under 18 population and adults. The phrase "Adolescents commit more armed robberies than adults" is followed by "no matter that the number of minors committing crimes is smaller" ("sin importar que el número de menores delinquiendo sea más pequeño"). While it mentions that adults in general do commit more crimes than youngsters (as both independent and government statistics indicate), this is removed from the focus of attention by explicitly construing this as a fact not to be noted (by "no matter that..."). Moreover, there is no mention of the actual number of armed robberies that either of these two groups commits, nor of the true proportion of these within the total number of crimes. It is only mentioned that adolescents commit more armed robberies with no further numbers given that could clarify and contextualize the situation, such as what the total number of robberies and other crimes in both populations is, how this number has increased, what is the total population of adolescents and adults, by what socioeconomic factors this increase might have occurred, etc. The one-dimensional construal that is forwarded in the example helps to link adolescents more strongly with armed robberies, by making a claim based on (unclear) statistics, and presenting violent robberies as if these constituted a type of crime belonging to adolescents themselves. Furthermore, such constructions only serve to replay and perpetuate widespread misapprehensions that minors were somehow responsible for the larger number of crimes in Uruguay.

Example 8 also brings youngsters into the universe of crime, by reporting on a group of three minors robbing a health clinic. What is interesting about this example is the contextual information about the Robbery EF being construed here. The circumstantial clause "While traders and neighbours prepared for a march to demand safety" specifies the time that the robbery took place, and this makes this crime even more impactful because of the contrast (and even irony) posed by the fact that a robbery was happening while groups of people were marching demanding better security measures. The emotional impact of such a portrayal helps to set up a contrast between two social groups, minors and traders and neighbours, the former being construed as victimizers and a different "other", the latter being represented as closer to the readership (who may be workers themselves) and vulnerable to the onslaught of minors.

From the previous cases and the observations made from the macro-level analysis it becomes clearer that the concept of "minor", which in Uruguay used to be employed to refer to a more neutral legal status (i.e. of people under the legal age of adulthood and sexual consent) or to youngsters under the care of the State and their parents (see UNICEF, 2006), is now stained 
with a negative tint and very strongly associated with delinquency. Beyond the use of lexical items related to crime when nominating minors in these reports, minors are represented as perpetrators of violent crimes indirectly, via quotes of what they purportedly remark while committing these crimes. For example, within the sample we find:

\section{Original}

10) En ámbitos judiciales y policiales trascendió que los menores actúan con cada vez más violencia en sus rapiñas a comerciantes o a transeúntes. "Los 'fierros' son para utilizarlos", declaró un menor homicida en un Juzgado de Adolescentes.

11) "No nos importa nada, somos menores de edad", dijo otro de los delincuentes, al tiempo que amenazaba hacer volar el local con la granada que tenía en la mano.
Translation

In courts and police contexts it was revealed that minors act with increasing violence in their armed robberies to traders or passerbyes. "'Gats' are meant to be used", declared a homicidal minor in a Juvenile Court.

"We don't give a damn, we are
minors" said one of the other
delinquents, while he threatened to blow
up the store with the grenade in his hand.

Adding these quotes means it is minors who are representing themselves as violent, although the sources of these words are never explicitly identified. This is the only way in which the voice of minors is brought forth in these reports, i.e. in their role of Perpetrators, where they display a dismissive and violent tone. Example 11 is particularly interesting as it comes from a report which achieved a great deal of media coverage for the offenders' use of assault weapons (grenades and rifles) and for what was considered by many to be a display of outrageous indifference on their part towards their actions. What is most interesting in the context of the debate is the fact that many advocates of the reform claimed that minors were not prosecutable under the present laws and that they were knowingly using this to get away with their crimes. Actually quoting one minor exhibiting the very same behaviour that reformers sustained was true for all of them was taken as evidence in support of this claim and arguably served to reinforce the construal of minors as callous criminals. More importantly, the report seems to play into the fears of the social collective, potentially making the argument of reformers harder to counteract.

\section{Closing Remarks}

Throughout this study I have attempted to show that the most widespread Uruguayan media outlet is involved in a systematic disparagement of young adolescents by choosing to report on their involvement crime (even without statistical support to make such reporting reliable and proportionate). When brought down to the realm of everyday social action, the relevance of this lies on the fact that, if these conceptualisations are to figure long and saliently enough in the public's sphere of attention and remain unquestioned, associations such as the ones uncovered in this study run the risk of becoming entrenched and of fuelling dangerous assumptions about one of the most vulnerable and hotly debated social collectives in Uruguay. Reinforcing the semantic links of delinquency and minority facilitates the dissociation of the concept "minor" from its more traditional conceptual domains (in Uruguay, the word minor used to be employed to refer to citizens under the legal age of sexual consent and adulthood or to people under the care of the State and/or parents or guardians), and from the position of these social actors as victims of violence themselves. In other words, it serves to conceptualise minors as inherently conflictive, and makes it ostensibly easier to conceptualise certain people under 18 as adults and thus to introduce them in a legal framework applied to adults. 
Of course, in such a brief study, there were many lines of enquiry that could not be explored to their full extent. This leaves open numerous avenues through which investigations like the present one could be advanced and improved upon. In this instance, I have tried to integrate a range of theoretically compatible methods for the analysis of discourse and cognitive construals. Incursions into experimental methods for integration with CL-CDS can provide studies on the interplay of cognition, discourse and sociopolitical action with augmented explanatory power.

Especially for CL-CDS, insights from psychology, sociology and even neurosciences should at least be consulted, as these are areas of enquiry with long-lived traditions of studying human representations and behaviour in social collectives. Indeed, such studies have already made valuable incursions into the relationship between language, cognition and the formation of impressions towards other social actors (e.g. Higgins, Roles and Jones, 1977; Hernandez \& Preston, 2013), and some have even probed the effects of media texts on decision-making (e.g. in the granting of refugee status to asylum seekers in Lido, 2006) and evaluative judgments (e.g. towards mental health patients in Dietrich et al., 2006). The lines of enquiry of these investigations and the results obtained seem to lend some credibility to the notion, widespread throughout CDA methodologies, and argued for in this study, that linguistic constructions have a constitutive role in the construction of perceptions and judgements of other social actors. It should be borne in mind, however, that despite their marked interest in uncovering the impact of language and media texts on perception, no systematic linguistic analysis is performed of the input texts to which participants are exposed, to the effect that there is little clarity as to which linguistic structures can be considered as having an impact on subsequent social judgments (and to what extent they do). This is where CL-CDS can make a methodological contribution. Future studies which seek to further uncover the mental structures behind the formation of ideologies and social behaviour within CL-CDS can lend their range of methods for the analysis of discourse, while benefitting from experimental approaches to test some of its foundational claims. In other words, future lines of research could work to bring the theoretical and methodological body of CL-CDS to the proximity of contemporary empirical research on cognition and social behaviours. Explorations of the neural embodiment of ideology, discrimination and stereotyping discourses, for example, constitute a newly forming research trend in CL-CDS, one which could provide interesting and grounded revelations in the study of social problematics, and the demystification of ideology. 


\section{REFERENCES}

Baker C, Fillmore C and Lowe J (1998) The Berkeley FramNet Project. In: COLING '98 Proceedings of the $17^{\text {th }}$ international conference on computational linguistics - Vol 1 , pp.86-90.

Bureau of Human Rights (2013) Uruguay 2013 Human Rights Report. Report for the United States Department of State. Available at: http://www.state.gov/documents/organization/220687.pdf (accessed 24 August 2014).

CEPAL (2010) Pobreza infantil en América Latina y el Caribe. Santiago de Chile: CEPAL y UNICEF.

Charteris-Black J (2006) Britain as a container: immigration metaphors in the 2005 election campaign. Discourse \& Society, 17(5):563-581.

Chilton P (2004) Analysing Political Discourse: Theory and practice. London: Routledge.

Chilton P (2005) Missing links in mainstream CDA: Modules, blends and the critical instinct In Wodak, $\mathrm{R}$ and Chilton, $\mathrm{P}$ (eds) A New Research Agenda in Critical Discourse Analysis: Theory and Interdisciplinarity. Amsterdam: John Benjamins, pp. 19-52.

Chilton P (2011) Still something missing in CDA. Discourse Studies 13(6):769-781.

Croft W and Cruse D (2004) Cognitive Linguistics. Cambridge: Cambridge University Press.

Dietrich S, Heider D, Matschinger H, Angermeyer M (2006) Influence of newspaper reporting on adolescents' attitudes toward people with mental illness. Social Psychiatry and Psychiatric Epidemiology 41:318-322.

Divjak D and Caldwell-Harris CL (2015) Frequency and entrenchment. In: Dabrowska E and Divjak D (eds) Cognitive Foundations of Language. Boston: Mouton De Gruyter.

El Refaie E (2001) Metaphors we discriminate by: Naturalized themes in Austrian newspaper articles about asylum seekers. Journal of Sociolinguistics 5(3):352-371.

Equipos Mori (2009) Amplio apoyo a reducir edad de imputabilidad penal. Available at: http://www.equipos.com.uy/noticia/amplio-apoyo-reducir-edad-de-imputabilidadpenal/ (accessed 18 June 2014).

Equipos Mori (2013) Un 64\% a favor de la baja de la edad de imputabilidad penal. Public Poll. Available at: http://www.equipos.com.uy/noticias_despliegue.php?i=136 (accessed 20 June 2014).

Fairclough N (1989). Language and Power. London: Longman.

Fairclough N (1992). Discourse and Social Change. Cambridge: Polity Press.

Fillmore C (1982) Frame semantics. In: The Linguistic Society of Korea (ed) Linguistics in the Morning Calm. Seoul: Hanshin, pp.111-37.

Fillmore, C. J. and Baker, C. (2009). A Frames Approach to Semantic Analysis. In: Heine B and Narrog H (eds) The Oxford Handbook of Linguistic Analysis. New York: Oxford University Press, pp.272-301.

Fiske, S. T., \& Taylor, S. E. (1991). Social cognition (2nd ed.). New York: McGraw-Hill.

Flowerdew, J (1999) Description and interpretation in Critical Discourse Analysis. Journal of Pragmatics, 31, 1089-1099.

FrameNet Project (2014) http://www.icsi.berkeley.edu/ framenet/ (accessed 20 July 2014)

Gerbner G, et al. (1986) Living With Television: The Dynamics of the Cultivation Process. In: Bryant J and Zillman D (eds) Perspectives on Media Effects. New Jersey: Lawrence Erlbaum, pp. 17-40.

Gilbert D and Hixon J (1991) The trouble of thinking: Activation and application of stereotypic beliefs. Journal of Personality and Social Psychology 60:509-517.

Hart C (2008) Critical discourse analysis and conceptualisation: Mental spaces, blended spaces and discourse spaces in the British National Party. In: Hart C and Lukeš D (eds) Cognitive Linguistics in Critical Discourse Analysis: Application and theory. Newcastle: Cambridge Scholars Publishing, pp. 107-131. 
Hart C (2010) Critical Discourse Analysis and Cognitive Science: New Perspectives on Immigration Discourse. Basingstoke: Palgrave Macmillan.

Hart C (2011a) Moving beyond Metaphor in the Cognitive Linguistic Approach to CDA: Construal Operations in Immigration Discourse. In: Hart C (ed), Critical Discourse Studies in Context and Cognition. Amsterdam: John Benjamins, pp.71-92.

Hart C (2011b) Force-interactive patterns in immigration discourse: A Cognitive Linguistic approach to CDA. Discourse \& Society 22(3):269-286.

Hart C (2014) Discourse. In E. Dabrowska and D. Divjak (eds.), Handbook of Cognitive Linguistics. Berlin: Mouton De Gruyter.

Hart C (2015) Discourse, Grammar and Ideology: Functional and cognitive perspectives. London: Bloomsbury.

Hernandez, I., \& Preston, J.L. (2013). Disfluency disrupts the confirmation bias. Journal of Experimental Social Psychology, 49, 178-182.

Higgins ET, Rholes WS and Jones CR (1977) Category accessibility and impression formation. Journal of Experimental Social Psychology, 13(2), 141-154.

Hunston, S (2002) Corpora in Applied Linguistics. Cambridge: Cambridge University Press.

InFamilia (2009) Prácticas de crianza y resolución de conflictos familiares. Prevalencia del maltrato intrafamiliar contra niños y adolescentes. Montevideo: MIDES.

Julios-Costa M (forthcoming) Semantic representations in media texts affect perceptions of young offenders: An experimental case study in Cognitive Semantics, Conceptual Priming and Critical Discourse Analysis.

Kaal B (2012) Worldviews: Spatial ground for political reasoning in Dutch Election manifestos. CADAAD 6(1):1-22.

Koller V (2004) Metaphor and Gender in Business Media Discourse: A Critical Cognitive Study. Basingstoke: Palgrave.

Lakoff G (1996) Moral Politics: How Liberals and Conservatives Think. Chicago: University of Chicago Press.

Lido, C. (2006) Effects of the media priming asylum-seeker stereotypes on thoughts and behaviour. RES-000-22-0773. ESRC, London, UK.

Musolff A (2010) Metaphor, Nation and the Holocaust. The Concept of the Body Politic. London/New York: Routledge.

United Nations (2009) UN rights expert urges Uruguay to end 'appalling' prison conditions. UN News Centre, 27 March.

O' Halloran K (2009) Casualness vs Commitment: The Use in CDA of Lakoff and Johnson's Approach to Metaphor. In: Hart C and Lukeš D (eds) Cognitive Linguistics in Critical Discourse Analysis: Application and theory, pp.107-131. Newcastle: Cambridge Scholars Publishing.

Paternain R (2008) Panorama de la Violencia, la Criminalidad y la Inseguridad en el Uruguay. Montevideo: PNUD-Ministerio del Interior.

Paternain R (2012) Violencia y Criminalidad en Uruguay: una mirada macrorregional. Montevideo. Facultad de Ciencias Sociales - UdelaR. Available at: www.fcs.edu.uy/archivos/08\%20Paternain.pdf (accessed 12 June 2014).

Radakovich R, Escuder S, Morales M, Ponce M (2013) Mapping Digital Media: Uruguay. Open Society Foundation, London. Available at: https://www.opensocietyfoundations.org/sites/default/files/mapping-digital-mediauruguay-20131128.pdf (accessed 13 May 2014)

Reisigl M and Wodak R (2001) Discourse and Discrimination: Rhetorics of Racism and Anti-Semitism. London: Routledge.

Sánchez-García, J. \& Blanco-Carrión, O. (2007). Frames and Critical Discourse Analysis in Violence-Related Emotive Event Analysis. In C. Hart \& D. Lukeš (Eds.) Cognitive 
Linguistics in Critical Discourse Analysis: Application and theory. Cambridge:

Cambridge Scholars Publishing.

Sánchez-García, J. (2007). Toward a cognitively-oriented Critical Discourse Analysis:

Framing, construal and violence-related emotional meaning. In C. Hart \& D. Lukeš

(Eds.) Cognitive Linguistics in Critical Discourse Analysis: Application and theory.

Cambridge: Cambridge Scholars Publishing.

UNICEF (2006) Justicia y participación adolescente. Palabras y juegos. Available at: http://www.unicef.org/uruguay/spanish/GUIA 4.pdf (accessed 19 July 2014).

UNICEF (2010) Aportes al Debate sobre Seguridad Ciudadana y Adolescentes en Conflicto con la Ley. Available at:

http://www.unicef.org/uruguay/spanish/aportes al debate sobre JPA 1510102 (accessed 20 June 2014).

UNICEF (2012) Observatorio de los Derechos de la Infancia y la Adolescencia en Uruguay 2012. Annual Report. Available at:

http://www.unicef.org/uruguay/spanish/observatorio-2012-web20121030.pdf (accessed 19 June 2014).

UNICEF (2014) Aportes para la cobertura periodística sobre la rebaja de la edad de imputabilidad. Uruguay, August. Available at:

http://www.unicef.org/uruguay/spanish/unicef-edad-imputabilidad.pdf (accessed 18 November 2014).

Van Dijk TA (2009) Critical discourse studies: a sociocognitive approach. In: Wodak R and Meyer M (eds). Methods of Critical Discourse Analysis, pp. 62-86. London: Sage.

Van Dijk TA (2008) Discourse and Context: A Socio-cognitive Approach. Cambridge: Cambridge University Press.

Vilela-Sánchez R (2006) Infancia y Violencia en los medios. Montevideo: UNICEF.

Voz y Vos (2011) Adolescentes en conflicto con la Ley en la Prensa Uruguaya. Available at: http://www.vozyvos.org.uy/index.php/temas/3053/adolescentes-en-conflicto-con-laley (accessed 14 June 2014).

Wodak, R. (2006). Mediation between discourse and society: Assessing cognitive approaches in CDA. Discourse Studies 8 (1): 179-190.

Wodak R and Meyer M (2009) Critical discourse analysis: history, agenda, theory and methodology. In: Wodak R and Meyer M (eds) Methods of Critical Discourse Analysis, pp. 1-33. London: Sage. 
APPENDIX 2 - Collocates of "minor*", "adolescent"" and "child*".

40 Strongest Collocates of "Minor"” by t-score.

\begin{tabular}{|c|c|c|c|c|c|c|}
\hline Rank & $\begin{array}{l}\text { Total } \\
\text { Frequency }\end{array}$ & Freq. Left & $\begin{array}{l}\text { Freq. } \\
\text { Right }\end{array}$ & t-score & Word Type & Translation \\
\hline 1 & 149 & 17 & 132 & 11.96059 & años & years \\
\hline 2 & 106 & 4 & 102 & 10.25737 & infractores & offenders \\
\hline 3 & 106 & 3 & 103 & 10.2134 & edad & age \\
\hline 4 & 74 & 68 & 6 & 8.53178 & antecedentes & criminal records \\
\hline 5 & 50 & 13 & 37 & 6.98974 & delitos & felonies \\
\hline 6 & 43 & 37 & 6 & 6.51714 & penas & sentences \\
\hline 7 & 41 & 17 & 24 & 6.16925 & inau & INAU \\
\hline 8 & 33 & 26 & 7 & 5.6402 & juez & judge \\
\hline 9 & 31 & 2 & 29 & 5.53085 & internados & interned \\
\hline 10 & 31 & 26 & 5 & 5.49305 & fiscal & district attorney \\
\hline 11 & 31 & 25 & 6 & 5.4535 & justicia & justice \\
\hline 12 & 23 & 23 & 0 & 4.72746 & internación & internment \\
\hline 16 & 23 & 20 & 3 & 4.71624 & juzgado & courthouse \\
\hline 14 & 22 & 20 & 2 & 4.61477 & jueza & judge (fem.) \\
\hline 15 & 22 & 15 & 7 & 4.59181 & libertad & freedom \\
\hline 16 & 20 & 14 & 6 & 4.41359 & jueces & judges \\
\hline 17 & 19 & 1 & 18 & 4.34093 & fugado & escaped \\
\hline 18 & 19 & 2 & 17 & 4.3168 & detenidos & arrested \\
\hline 19 & 19 & 18 & 1 & 4.29995 & judiciales & judicial (pl.) \\
\hline 20 & 18 & 17 & $\frac{1}{1}$ & 4.09845 & madre & mother \\
\hline 21 & 16 & 14 & 2 & 3.95657 & juzgados & courthouses \\
\hline 22 & 16 & 5 & 11 & 3.86419 & hogar & home \\
\hline 23 & 15 & 10 & 5 & 3.75926 & contra & against \\
\hline 24 & 14 & 0 & 14 & 3.72073 & cometen & commit (crimes) \\
\hline 25 & 14 & 3 & 11 & 3.68476 & zubía & Zubía (surname) \\
\hline 26 & 14 & 11 & 3 & 3.58339 & padres & parents \\
\hline 27 & 13 & 1 & 12 & 3.58316 & cometieron & $\begin{array}{l}\text { committed } \\
\text { (crimes) }\end{array}$ \\
\hline 28 & 13 & 1 & 12 & 3.58044 & barreto & $\begin{array}{l}\text { Barreto } \\
\text { (surname) }\end{array}$ \\
\hline 29 & 15 & 11 & 4 & 3.57982 & policía & police \\
\hline 30 & 12 & 0 & 12 & 3.44644 & infractor & offender \\
\hline 31 & 12 & 1 & 11 & 3.44574 & homicida & murderer \\
\hline 32 & 12 & 11 & 1 & 3.44008 & cometidos & commited (pl.) \\
\hline 33 & 12 & 0 & 12 & 3.43726 & vera & Vera (surname) \\
\hline 34 & 12 & 2 & 10 & 3.43161 & sayagués & $\begin{array}{l}\text { Sayagués } \\
\text { (surname) }\end{array}$ \\
\hline 35 & 13 & 4 & 9 & 3.42638 & montevideo & Montevideo \\
\hline 36 & 12 & 12 & 0 & 3.41607 & sexual & sexual \\
\hline 37 & 14 & 10 & 4 & 3.3218 & adolescentes & adolescents \\
\hline 38 & 11 & 2 & 9 & 3.30187 & fugados & escaped (pl.) \\
\hline 39 & 12 & 7 & 5 & 3.30163 & sistema & system \\
\hline 40 & 11 & 8 & 3 & 3.29006 & cometido & commited (sing.) \\
\hline
\end{tabular}


40 Strongest Collocates of "Adolescent"” by t-score.

\begin{tabular}{|c|c|c|c|c|c|c|}
\hline Rank & $\begin{array}{l}\text { Total } \\
\text { Frequency }\end{array}$ & $\begin{array}{l}\text { Freq. } \\
\text { Left }\end{array}$ & $\begin{array}{l}\text { Freq. } \\
\text { Right }\end{array}$ & t-score & Word Type & Translation \\
\hline 1 & 91 & 90 & 1 & 9.40085 & niños & children \\
\hline 2 & 68 & 68 & 0 & 8.20142 & penal & penal \\
\hline 3 & 70 & 8 & 62 & 8.11811 & años & years \\
\hline 4 & 39 & 2 & 37 & 6.21434 & sirpa & $\begin{array}{l}\text { SIRPA (system of } \\
\text { adolescent penal } \\
\text { responsibility) }\end{array}$ \\
\hline 5 & 40 & 38 & 2 & 6.1965 & niño & child \\
\hline 6 & 37 & 3 & 34 & 6.03012 & uruguay & Uruguay \\
\hline 7 & 36 & 0 & 36 & 5.95453 & infractores & offenders \\
\hline 8 & 34 & 4 & 30 & 5.65311 & inau & INAU \\
\hline 9 & 29 & 22 & 7 & 5.15894 & dos & two \\
\hline 10 & 26 & 22 & 4 & 5.07609 & madres & mothers \\
\hline 11 & 23 & 23 & 0 & 4.70821 & antecedentes & criminal records \\
\hline 12 & 20 & 14 & 6 & 4.33726 & uno & one \\
\hline 13 & 20 & 13 & 7 & 4.32021 & tres & three \\
\hline 14 & 18 & 17 & 1 & 4.18034 & $\overline{\text { juzgado }}$ & courthouse \\
\hline 15 & 16 & 0 & 16 & 3.97247 & villaverde & $\begin{array}{l}\text { Villaverde } \\
\text { (surname) }\end{array}$ \\
\hline 16 & 16 & 7 & 9 & 3.90046 & delitos & felonies \\
\hline 17 & 15 & 15 & 0 & 3.85505 & embarazo & pregnancy \\
\hline 18 & 15 & 2 & 13 & 3.83623 & internados & interned \\
\hline 19 & 15 & 14 & 1 & 3.83317 & niñas & girls \\
\hline 20 & 14 & 6 & 8 & 3.65607 & libertad & freedom \\
\hline 21 & 13 & 12 & 1 & 3.48337 & justicia & justice \\
\hline 22 & 12 & 11 & 1 & 3.44747 & cometidos & $\begin{array}{l}\text { committed } \\
\text { (crimes) }\end{array}$ \\
\hline 23 & 16 & 7 & 9 & 3.41925 & menores & minors \\
\hline 24 & 13 & 3 & 10 & 3.30056 & dijo & said \\
\hline 25 & 11 & 4 & 7 & 3.25379 & rapiñas & armed robberies \\
\hline 26 & 11 & 4 & 7 & 3.20219 & situación & $\begin{array}{l}\text { situation (of } \\
\text { homelessness) }\end{array}$ \\
\hline 27 & 10 & 10 & 0 & 3.13334 & porcentaje & percentage \\
\hline 28 & 10 & 9 & 1 & 3.03261 & padres & parents \\
\hline 29 & 10 & 6 & 4 & 3.031 & juez & judge \\
\hline 30 & 9 & 6 & 3 & 2.9599 & $\overline{\text { juzgados }}$ & courthouses \\
\hline 31 & 9 & 9 & 0 & 2.92432 & internación & internment \\
\hline 32 & 8 & 4 & 4 & 2.77272 & mayoría & majority \\
\hline 33 & 9 & 8 & 1 & 2.75883 & año & year \\
\hline 34 & 8 & 5 & 3 & 2.72539 & mayor & adult \\
\hline 35 & 8 & 4 & 4 & 2.72479 & trabajo & labor (illegal) \\
\hline 36 & 8 & 8 & 0 & 2.70502 & cuatro & four \\
\hline 37 & 8 & 1 & 7 & 2.68346 & jóvenes & youngsters \\
\hline 38 & 7 & 2 & 5 & 2.62654 & embarazadas & pregnant \\
\hline
\end{tabular}




\begin{tabular}{|l|l|l|l|l|l|l|}
\hline 39 & 7 & 0 & 7 & 2.62462 & cometieron & $\begin{array}{l}\text { committed }\left(3^{\text {rd }} \mathrm{p} .\right. \\
\text { pl. })\end{array}$ \\
\hline 40 & 7 & 2 & 5 & 2.60348 & detenido & arrested \\
\hline
\end{tabular}

40 Strongest Collocates of "Child*" by t-score.

\begin{tabular}{|c|c|c|c|c|c|c|}
\hline Rank & $\begin{array}{l}\text { Total } \\
\text { Frequency }\end{array}$ & $\begin{array}{l}\text { Freq. } \\
\text { Left }\end{array}$ & $\begin{array}{l}\text { Freq. } \\
\text { Right. }\end{array}$ & t-score & Word Type & Translation \\
\hline 1 & 182 & 13 & 169 & 13.19898 & años & years \\
\hline 2 & 109 & 5 & 104 & 10.24305 & adolescentes & adolescents \\
\hline 3 & 64 & 43 & 21 & 7.7117 & dos & two \\
\hline 4 & 40 & 1 & 39 & 6.11559 & adolescente & adolescent \\
\hline 5 & 35 & 34 & 1 & 5.86132 & derechos & rights \\
\hline 6 & 34 & 34 & 0 & 5.76274 & instituto & $\begin{array}{l}\text { institute } \\
\text { (INAU) }\end{array}$ \\
\hline 7 & 31 & 27 & 4 & 5.42373 & madre & mother \\
\hline 8 & 27 & 16 & 11 & 4.9486 & tres & three \\
\hline 9 & 20 & 9 & 11 & 4.28995 & familia & family \\
\hline 10 & 19 & 17 & 2 & 4.05423 & caso & $\begin{array}{l}\text { case } \\
\text { (medical) }\end{array}$ \\
\hline 11 & 15 & 14 & 1 & 3.74378 & día & day \\
\hline 12 & 16 & 8 & 8 & 3.65757 & año & year \\
\hline 13 & 16 & 7 & 9 & 3.50921 & inau & INAU \\
\hline 14 & 12 & 6 & 6 & 3.37057 & seis & six \\
\hline 15 & 11 & 6 & 5 & 3.26246 & falleció & died \\
\hline 16 & 11 & 10 & 1 & 3.22668 & muerte & death \\
\hline 17 & 12 & 7 & 5 & 3.16222 & ayer & yesterday \\
\hline 18 & 12 & 2 & 10 & 3.1437 & edad & age \\
\hline 19 & 11 & 4 & 7 & 3.09997 & situación & situation \\
\hline 20 & 10 & 10 & 0 & 3.09026 & atención & $\begin{array}{l}\text { attention (to } \\
\text { children) }\end{array}$ \\
\hline 21 & 11 & 10 & 1 & 3.08256 & padres & parents \\
\hline 22 & 11 & 9 & 2 & 3.06516 & casos & $\begin{array}{l}\text { cases } \\
\text { (medical) }\end{array}$ \\
\hline 23 & 10 & 7 & 3 & 3.03041 & vida & life \\
\hline 24 & 9 & 0 & 9 & 2.97327 & uruguayos & Uruguayan \\
\hline 25 & 9 & 7 & 2 & 2.96151 & adopción & adoption \\
\hline 26 & 9 & 9 & 0 & 2.92729 & sexual & sexual \\
\hline 27 & 9 & 7 & 2 & 2.90484 & cargo & in charge of \\
\hline 28 & 9 & 7 & 2 & 2.87062 & padre & father \\
\hline 29 & 9 & 1 & 8 & 2.82357 & hoy & today \\
\hline 30 & 9 & 6 & 3 & 2.80753 & contra & against \\
\hline 31 & 8 & 1 & 7 & 2.77626 & presentó & presented \\
\hline 32 & 8 & 4 & 4 & 2.77399 & Mercedes & $\begin{array}{l}\text { Mercedes } \\
\text { (town) }\end{array}$ \\
\hline 33 & 8 & 8 & 0 & 2.75131 & Rossell & $\begin{array}{l}\text { Rossell } \\
\text { (hospital) }\end{array}$ \\
\hline 34 & 8 & 2 & 6 & 2.74677 & siete & seven \\
\hline
\end{tabular}




\begin{tabular}{|l|l|l|l|l|l|l|}
\hline 35 & 8 & 6 & 2 & 2.72295 & familiares & relatives \\
\hline 36 & 8 & 7 & 1 & 2.70708 & infantil & $\begin{array}{l}\text { infantile } \\
\text { (abuse) }\end{array}$ \\
\hline 37 & 8 & 3 & 5 & 2.64697 & cinco & five \\
\hline 38 & 7 & 0 & 7 & & estudiados & $\begin{array}{l}\text { studied } \\
\text { (participle } \\
\text { pl.) }\end{array}$ \\
\hline 39 & 8 & 7 & 1 & 2.63484 & madult \\
\hline 40 & 8 & 3 & 5 & 2.5948 & cuatro & four \\
\hline
\end{tabular}

NOTE: As with word frequencies, in the collocate lists, the dark red color corresponds to words within the CRIME frame, while the light blue marking is for words within the frame LAW \& INSTITUTIONS. It should be noted that in the texts these institutions are almost exclusively related to crime events (i.e. these are institutions that appear as frame elements in CRIME event frames). The light red color marks words activating the frame of ABUSE \& VULNERABILITY; dark blue corresponds to words within the frame PARENTING \& GUARDIANSHIP; yellow is for words profiling HEALTH, and green for words related to PROTECTING \& RESCUING.

Almost all of the collocates of "minor*" belong to the frames CRIME and LAW \& INSTITUTIONS. In the texts, minors are agents of crime or recipients of punishment by the law. Similarly, adolescents in this corpus are constructed in relation to criminality (in their role of perpetrators) and to the penal law being applied to them (note the frequent appearance of words in the frame of LAW \& INSTITUTIONS and CRIME). Thus, adolescents are frequent agents in felonies and their situation is dictated by institutions of social control. Issues where they are involved in teen pregnancy and substance abuse are also present (as indicated by words in yellow -from the HEALTH frame), and this, it could be argued, contributes to an altogether negative valuation of adolescents across the discourses of this newspaper. In the case of "children", this node word is reserved for cases where youngsters are victims of negligence and abuse (light red), and they are also conceptualised in relation to their bonds of kinship with adults -who are the main agents in the mistreatment of children (dark blue). In a similar proportion, issues around health and diseases are strongly associated with children, and it is only very seldom that children are associated with more positive and empowering concepts. They thus seem to be disempowered social actors who are systematically involved as sufferers in negatively perceived events.

\section{APPENDIX 3 - Input articles from broader corpus}

\section{Menores cometen tres delitos por día}

Accessed: 10 May 2014 - http://historico.elpais.com.uy/12/12/16/pnacio 682232.asp

Estadísticas. Este año los casos en los juzgados de adolescentes superarán los 1.000

Tres delitos por día cometieron menores de edad en el correr de 2012 en Montevideo, según datos relevados en los cuatro juzgados de Adolescentes. La gran mayoría de ellos fueron robos violentos.

Estadísticas del Poder Judicial señalan que la participación de los menores en delitos en general ha ido en aumento en los últimos años.

En 2008, los adolescentes enfrentaron 760 procesos. En tanto los adultos, 4.521. Eso significa que los menores cometieron el $14 \%$ de los delitos. 
Las cifras del Poder Judicial muestran que, al año siguiente, subió la participación de los menores en el universo de ilícitos. En 2010 se mantienen los guarismos aunque hay una pequeña caída de los delitos protagonizados por menores. La Justicia procesó a 4.057 adultos $(83 \%)$ y a 842 menores $(17 \%)$.

El año pasado volvió a incrementarse la participación de adolescentes en la comisión de delitos. Las cifras de los juzgados señalan que en 2011 fueron procesados 3.979 adultos (82\%) y 873 adolescentes (18\%).

Las sentencias de los jueces de adultos y de menores tipifican el delito cometido por los mismos. Las cifras del Poder Judicial muestran que los adolescentes comenten más robos violentos que los adultos sin importar que el número de menores delinquiendo sea más pequeño.

La Policía estima que los menores infractores son unos 1.000 y que los delincuentes adultos en libertad son unos 10.000. Según operadores judiciales, la explicación de este fenómeno se debe que los menores reinciden en un período de tiempo menor que el de los adultos, ya que un delincuente mayor procesado por robo violento pasará cinco años tras las rejas, mientras que un adolescente estará internado en un hogar entre tres y cuatro meses por cometer el mismo delito.

\section{"Somos menores, no nos importa nada"}

Accessed: 10 May 2014 - http://historico.elpais.com.uy/12/06/05/pciuda_644758.asp

\section{Asalto. Armados hasta los dientes, cuatro delincuentes menores robaron un restaurante en Pocitos.}

Cuatro delincuentes, armados con escopetas, revólveres y hasta una granada, concretaron un robo violento contra un restaurante de Pocitos Nuevo. Tras una persecución dos delincuentes fueron capturados.

"Dame toda la guita o hacemos explotar todo", gritó uno de los delincuentes al ingresar al local de Iturriaga y Luis Alberto de Herrera, mostrando una granada en su mano.

"No nos importa nada, somos menores de edad", dijo otro de los delincuentes, durante el robo violento, al tiempo que amenazaba hacer volar el local con la granada que tenía en la mano.

\section{Ochenta menores asesinos internados}

\section{Accessed: 10 May 2014 - http://www.elpais.com.uy/informacion/ochenta-menores- asesinos-internados.html}

Ochenta menores homicidas se encuentran internados en la Colonia Berro y en los hogares de Montevideo. Nueve de ellos, de entre 13 y 17 años, tienen múltiples asesinatos, según datos estadísticos del Sistema de Responsabilidad Penal Adolescente (Sirpa).

Esos adolescentes derivados por hechos de sangre representan el 14\% de los 577 internos alojados con medidas privativas de libertad. 
El presidente del SIRPA, Rubén Villaverde, dijo a El País que, salvo pocas excepciones, los internos homicidas no generan disturbios durante sus internaciones. Indicó que en casos como los de "El Ricky" y "El Pelón" son continuamente cambiados de hogares por razones de seguridad.

El Sirpa cuenta con cuatro hogares de alta seguridad.

En ámbitos judiciales y policiales trascendió que los menores actúan con cada vez más violencia en sus rapiñas a comerciantes o a transeúntes. "Los 'fierros' son para utilizarlos", declaró un menor homicida en un Juzgado de Adolescentes.

Ante los comerciantes, los adolescentes optan por disparar primero para poder generar temor y llevarse el botín, según declararon.

\section{Banda de menores azota el barrio Colón}

\section{Accessed: 10 May 2014 - http://historico.elpais.com.uy/120117/pnacio- 619089/nacional/banda-de-menores-azota-el-barrio-colon/}

\section{Delincuencia. Tres menores de 8, 10 y 14 años, robaron una policlínica del Círculo Católico. Los vecinos de la zona se movilizaron en reclamo de mayor patrullaje y seguridad.}

Mientras comerciantes y vecinos de Colón preparaban una marcha para reclamar seguridad, la policlínica del Círculo Católico de ese barrio era asaltada por tres menores de 8, 10 y 14 años.

Los precoces delincuentes ingresaron a la policlínica Colón del Círculo Católico, próximo a las tres de la tarde. Los menores fueron directamente a la caja. Se acercaron a la encargada a quien le mostraron un arma de fuego y le dijeron "abrí o te mato". La encargada les abrió, y ni bien los menores traspasaron la puerta, tomaron de rehén a una auxiliar de enfermería que estaba en el lugar, poniéndole un arma en la cabeza.

"Estaban muy nerviosos, pero igualmente fueron violentos", contó la auxiliar. A su vez sostuvo que los menores "no tenían pinta de delincuentes". Uno de ellos tenía una mochila, donde guardaron el dinero que se llevaron.

El más chico traía puesta una camiseta de fútbol y los tres traían puesto gorros, "tipo cani", según el testimonio de la propia trabajadora.

También sostuvo que es la segunda vez que asaltan esta misma policlínica en seis meses. "La vez pasada también fueron menores, pero no tanto", contó. La auxiliar de enfermería, luego de ser tomada como rehén, sufrió una crisis nerviosa de la cual, dos horas después del atraco, no había podido salir. 


\section{Menores apedrean, asaltan, y vuelven a sus casas}

Accessed: 10 May 2014 - http://www.elpais.com.uy/informacion/menores-asaltanjusticia-devuelve.html

Al menos 12 menores de entre 13 y 17 años fueron detenidos en diez días por apedrear y robar a automovilistas en los accesos a Montevideo. Los envían a los juzgados y vuelven a casa, con sus "responsables". La Ruta 1 es una trampa para los conductores. 